\title{
DIE OPLEIDING VAN BEDRYFSIELKUNDIGES IN SUID-AFRIKA*
}

\section{VAN W. RAUBENHEIMER, C.J. CALITZ, W.S. DE VILLIERS EN J.C.D. AUGUSTYN \\ UNIVERSITEIT VAN STELLENBOSCH}

\section{INLEIDING}

Oor die afgelope aantal jare het bedryfsielkundiges in Suid-Afrika by verskeie geleenthede die mening gelug dat die tyd waarskynlik aangebreek het om die ontwikkeling van hul vakgebied hier te lande in oënskou te neem.

Hierdie behoefte het klaarblyklik ontstaan vanweë die snelle ontwikkeling wat die bedryfsielkunde die afgelope 10 tot 15 jaar in Suid-Afrika ondergaan het, vernaamlik in die praktiese beroeps- en bedryfslewe, aan akademiese instellings en in die beoefening van die bedryfsielkunde as 'n professie.

Waar die bedryfsielkunde ongeveer 'n dekade gelede 'n betreklik onbekende dissipline in openbare en privaatsektore was met ' $n$ uiters onsekere en vae omlyning (5), geniet die dissipline vandag 'n besondere aansien veral in topbestuurskringe van die bedryfswêreld (1, 2, 3, 4, 8).

Ook aan die akademiese instellings in Suid-Afrika het die bedryfsielkunde as toegepaste wetenskap voortdurend gegroei en ontwikkel. Tien jaar gelede is dit as onderafdeling van die sielkunde by slegs vier universiteite aangebied, terwyl slegs een universiteit oor 'n volwaardige bedryfsielkunde-departement beskik het. Tans word die vak aan 15 van die 16 universiteite in Suid-Afrika aangebied en bestaan daar ses outonome departemente van bedryfsielkunde. In hierdie dinamiese akademies-statutêre ontwikkeling van die bedryfsielkunde is dit opvallend dat die Afrikaanse universiteite die leidende rol veltolk het (6).

In die beoefening van die bedryfsielkunde as 'n professie, was daar oor die afgelope dekade onteenseglik fenomenale vooruitgang. ' $n$ Hele aantal konsultfirmas floreer vandag in Suid-Afrika en die daarstelling van 'n gesonde professionele infrastruktuur waarin aandag

\footnotetext{
* 'n Verslag oor samesprekings gehou op 24 September 1975 deur bedryfsielkundiges tydens die kongres van die Sielkundige Instituut van die R.S.A. aan die Randse Afrikaanse Universiteit.
} 
gegee kan word aan tariewe, etiese gedrag en implementeerbare wetlike registrasie, word 'n dringende behoefte.

Die fenomenale groei waarna verwys is, sou egter nie kon plaasvind sonder die stimulering wat van navorsingsinstansies uitgegaan het nie. In hierdie verband kan met erkenning verwys word na die belangrike werk wat oor die jare heen veral deur die Nasionale Instituut vir Personeelnavorsing en die Raad vir Geesteswetenskaplike Navorsing gedoen is.

Afgesien van die genoemde ontwikkeling en al die voordele wat daaruit voortgespruit het, blyk dit tog dat in die proses 'n aantal "middelpuntvlieënde kragte" momentum begin kry het wat die beoefenaar van die bedryfsielkunde noodsaak om aan homself rekenskap te gee; nie alleen van die wesentlike van dít waarmee hy homself besig hou nie, maar ook van hoedanig hy die ontwikkelingsgang in bepaalde rigtings kan stuur.

Die aansienlike uiteenlopendheid van kursusse wat by verskillende opleidingsinstansies aangebied word met die gevolglike verwarring oor wat die bedryfsielkundige is en kan doen, stem soms tot kommer. Die moeite wat 'n student ondervind wanneer hy sy studies wil voortsit aan 'n ander universiteit, lyk onnodig. Die onsekerheid wat daar soms bestaan oor die verhouding en verwantskap tussen die bedryfsielkunde en ander "moeder" en/of "suster" wetenskappe, weerspieël die gebrek aan eenstemmige oriëntasie wat uiteindelik tot 'n verwatering van die bedryfsielkunde self kan lei. Die matige onsekerheid wat daar bestaan oor wat die subvelde van die bedryfsielkunde is, kan onder geen omstandighede goedgepraat word nie. Al hierdie knelpunte en vele meer onderstreep die noodsaaklikheidvan 'n tydige maar kritiese selfondersoek.

Teen die agtergrond van wat in die voorafgaande paragrawe geskets is, is daar tydens die jaarlikse kongres van die Sielkundige Instituut van die R. S.A. (Sirsa) te Bloemfontein in 1974 'n versoek aan die Departement Bedryfsielkunde van die Universiteit van Stellenbosch gerig om die uitvoerbaarheid van 'n landswye samespreking oor die opleiding van bedryfsielkundiges te ondersoek en te reël indien moontlik.

Hierdie versoek het uitgeloop op die samestelling van 'n memorandum bestaande uit 51 vrae in verband met die aktiwiteite van die bedryfsielkundige in die praktyk, die akademie en die professie. 
Die 51 vrae, wat as riglyne sou dien vir 'n samespreking tussen bedryfsielkundiges tydens die jaarlikse kongres van Sirsa in 1975, is aan 'n groot aantal bedryfsielkundiges in die praktyk, akademie en professie gestuur vir studie en kommentaar.

Voorts is daar 'n versoek gerig aan altesaam 33 erkende bedryfsielkundiges in SuidAfrika om tydens die Sirsa-kongres deel te neem aan 'n ope vergadering en paneelbespreking wat sou sentreer rondom die vrae soos in die memorandum vervat.

Die doel van die samespreking is aan die kongresgangers voorgehou as hoofsaaklik informasiegenererend van aard. ' $\mathrm{n}$ Platform is geskep waar paneellede en kongresgangers menings, standpunte en inligting kon verstrek sonder om dringend te soek na probleemoplossings en antwoorde.

Dit is verder benadruk dat die inhoud van besprekings so ver moontlik toekomsgerig behoort te wees. Hierdie bepaling het noodsaaklik blyk te wees, aangesien die bedryfsielkunde in Suid-Afrika relatief onlangs eers begin wasdom bereik het en dat die akademiese ervaringe van die meeste kongresgangers, gesien die historiese ontwikkeling van die bedryfsielkunde in Suid-Afrika, besonder uiteenlopend moes gewees het.

Die toekoms kan na verwagting strenger, spesifieke eise aan die bedryfsielkundige stel en 'n mate van eenstemmigheid oor die opleiding van die bedryfsielkundige en die rol wat hy in die toekoms in die praktyk te vertolk het, sou die vak slegs tot voordeel strek.

Ten einde 'n gemeenskaplike verwysingsraamwerk daar te stel waarbinne die samesprekings gevoer kon word, was dit wenslik dat die begrip "bedryfsielkundige" vir die doeleindes van die samesprekings, soos volg omlyn word:

"Die bedryfsielkundige is iemand wat die bedryfsielkunde op voorgraadse vlak of op voor- en nagraadse vlak bestudeer het en wat deur 'n organisasie in diens geneem word vanweë die feit dat hy in die bedryfsielkunde studeer het."

Hoewel 'n gangbare definisie, wat die samesprekings aansienlik laat vlot het, het dit tog later geblyk (veral by die behandeling van vrae oor registrasie van bedryfsielkundiges by die Beroepsraad vir Sielkunde) dat daaraan sekere kwalifikasies gekoppel moet word. (Die oordeel van die kongresgangers oor hierdie spesifieke aangeleentheid behoort by die nalees van die hieropvolgende verslag duidelik te blyk.) 
In die aanbieding van die gebeurde tydens die samesprekings word die vrae in elke afdeling geformuleer soos wat dit in die oorspronklike memorandum verskyn het, waarop die ooreenstemmende reaksie tydens die samesprekings dan behandel word.

Aan sommige vrae kon daar, weens tydsdrukte, nie aandag geskenk word nie en dit word as sodanig aangedui.

\section{BEHOEFTES VAN DIE PRAKTYK}

Beroepsfere waarby bedryfsielkundiges betrek word

1. Hoedanig word bedryfsielkundiges na u mening in die volgende beroepsfere in SuidAfrika betrek? Meen u daar is ruimte vir verbetering? Indien wel, hoe kan dit tot stand gebring word?

a) Personeelwerk in openbare en privaatsektore

b) Beroepsleiding

c) Konsulteerwerk, bv. t.o.v. organisasie-ontwikkeling

d) Marknavorsing, produkbeplanning

e) Advertensies

f) Weermag

g) Gevangeniswese

h) Ander

1. Dit wil voorkom of die bedryfsielkundige (soos omlyn in bovermelde definisie) reeds by genoemde beroepe betrek word. Hoewel daar groot ruimte vir verbetering t.o.v. die benutting van sodanig gekwalifiseerde mense in die praktyk is, is die probleem waarskynlik nie soseer die benutting van sodanige persone nie, maar wel die verskaffing van mense met die nodige (relevante) opleiding.

Die beroepsfeer waar die bedryfsielkundige hom waarskynlik die meeste in bevind is personeelwerk, terwyl betreklik min in byvoorbeeld advertensiewese aangetref word. Die feit dat minder mense hulle tans in sekere beroepsfere bevind as in ander, beteken nie noodwendig dat daar minder aandag aan gegee moet word in die opleiding van bedryfsielkundiges nie. 
Plek van die bedryfsielkundige in organisasiestrukture (hiërargieë)

1. Wat is na u mening die huidige toestand? Indien dit nie bevredig nie, waarom nie?

2. Wat sou volgens u die ideale toestand wees?

1. In die algemeen wil dit voorkom asof die bedryfsielkundige, organisatories gesien, 'n plek vind in die personeelafdeling of subafdelings daarvan soos byvoorbeeld in 'n personeelontwikkelingsafdeling. 'n Persoon wat die bedryfsielkunde as een van sy studierigtings deurloop het, word egter nie noodwendig deur die onderneming aangestel as bedryfsielkundige nie, maar word aangestel om later 'n bestuurs- of lynpos te beklee.

In Suid-Afrika is daar wel genoegsame groot ondernemings om die bedryfsielkundige te gebruik as gedink word aan die bedryfsielkundige as "vakkundige" en selfs dán word daar gevind dat sulke vakkundiges later oorbeweeg na 'n lyn- (bestuurs-) pos.

Groter ondernemings in Suid-Afrika wend vandag daadwerklike pogings aan om gekwalifiseerde persone met bedryfsielkunde as agtergrond aan te stel in hul personeeldepartemente - by hoof- sowel as streekskantore.

'n Behoefte wat in Suid-Afrika egter al hoe meer op die voorgrond tree, is die behoefte aan Bantoe personeelamptenare met die nodige akademiese agtergrond.

Gebaseer op 'n studie (2) aangehaal tydens die samesprekings, word dit aanvaar dat daar in die afgelope aantal jare in Suid-Afrika ' $n$ vinnige toename in die personeel van personeeldepartemente was - 'n hoër persentuele groei as vir die totale personeel van ondernemings. Verder was daar ook 'n groter toename in die aantal bedryfsielkundiges in personeeldepartemente as in die geval van anders gekwalifiseerdes.

$\mathrm{Na}$ aanleiding van die voorafgaande menings, kom 'n verdere vraag na vore, naamlik "tot watter mate is 'n persoon 'n 'bedryfsielkundige' en tot watter mate is hy 'n 'bestuurder'?"

Vanuit die praktyk se hoek gesien, b1yk dit dat namate 'n persoon vorder in die organisasie hiërargie, hy minder van 'n spesialis en meer van 'n bestuurder word. In hierdie opsig vorm die sosiale wetenskappe 'n a1 hoe belangriker deel van sy akademiese toerusting en sal dit in die toekoms al hoe meer 'n vereiste word.

Wanneer 'n persoon by die onderneming aangeste 1 word, is dit nie normaalweg die gebruik dat hy dadelik begin met die toepas van allerlei bedryfsielkundige tegnieke nie. Dit word trouens noodsaaklik geag dat so 'n persoon eers algemene ondervinding van die fungering van die onderneming sal opdoen. 
2. Dit blyk dat daar in Suid-Afrika nie 'n definitiewe omlynbare posisie is wat die bedryfsielkundige in organisasiestrukture inneem nie. Dit wil eerder voorkom asof die benutting van die bedryfsielkundige grootliks bepaa1 word deur die besondere geskiedenis, karakter en bestuursfilosofie van e1ke besondere organisasie.

\section{Funksies van die bedryfsielkundige in 'n organisasie}

1. Op watter funksies kan die bedryfsielkundige opreg aanspraak maak om te vervul?

2. Is daar na u mening enige klemverskuiwing t.o.v. die vereistes wat aan die

\section{bedryfsielkundige in die toekoms gestel gaan word?}

1. Die bedryfsielkundige kan en behoort by alle funksies in 'n organisasie betrek te word waar wetenskaplike kennis aangaande die gedrag van die mens ter sprake kom. Teen so 'n breë agtergrond gesien, mag dit in die toekoms gebeur dat die begrip "bedryfsielkundige" wyer omlyn sal moet word en dat die tradisionele subvelde van die vak aangevul sal moet word.

- $\quad$ Ander vakrigtings moet met die bedryfsielkunde gekombineer word, byvoorbeeld bedryfsekonomie, publieke administrasie, staats1eer, vo1kekunde, Bantoetale,ens. By vakkombinasies moet egter uitgemaak word of die student uiteindelik as vakkundige in die onderneming opgeneem gaan word en of hy 'n 1yn-(bestuurs) posisie gaan beklee.

- $\quad$ 'n Veel breër kennis (opleiding dus) sal in die toekoms vereis word. Hier word veral gedink aan die agtergrond, houding en motivering van die nie-blanke werker, veral die Bantoe.

- $\quad$ Meer aandag sal gegee moet word deur die bedryfsielkundige aan die hele proses van "aanpassing" van die mens in die beroepslewe - beroepsaanpassing, loopbaanbeplanning en voorligting dus, in vaktaal terme. Die subveld beroepsielkunde binne die bedryfsielkunde behoort derhalwe sterker uitgebou te word.

Dit bly 'n kritiese vraag (wat telkemale te berde gebring is en waaroor daar uiteenlopende menings nagehou is) of die universiteit 'n persoon moet oplei om 'n goeie bedryfsielkundige (dus 'n vakkundige in eie reg) te wees en of hy hom moet oplei om 'n goeie bestuurder te wees. By nadere beskouing wil dit egter tog blyk dat bestuurskundigheid eintlik vakkundigheid impliseer. Bestuurskundigheid, volgens die betekenis wat die praktyk daaraan Perspektiewe in die Bedryfsielkunde 19762.3 
heg, kom in der waarheid tot sy reg binne die subveld organisasie- en bestuursielkunde. Bedryfsielkundige vakkundigheid sluit dus bestuurskundigheid plus 'n hele reeks ander kundighede in.

Opleidingsvereistes wat die praktyk stel

1. Wat, meen $u$, is die behoeftes van die praktyk t.o.v. werknemers met

a) Basiese bedryfsielkundige opleiding?

b) Gespesialiseerde bedryfsielkundige opleiding?

c) Praktiese ervaring in bedryfsielkundige werk?

d) Spesifieke bedryfsielkundige vaardighede?

As agtergrond vir hierdie vraag moet in gedagte gehou word dat 'n onderneming groot kapitale investering in sy mensemateriaal maak en dus al hoe meer mense aanstel om die mannekragfunksies te hanteer. Daarom het ons bestuurders, vakkundiges sowel as navorsers nodig in die veld van die bedryfsielkunde.

1. a) en d) Die vraag wat onmiddellik na vore kom is hoedanig basiese opleiding gespieël moet word teen 'n meer spesifieke opleiding. Aan die een kant verseker basiese opleiding dat die individu se kennis nie so snel verouderd raak nie en dat hy oor die langtermyn meer bruikbaar vir 'n organisasie kan wees. Aan die ander kant wil dit voorkom asof die praktyk van 'n persoon met bedryfsielkundige kwalifikasies verwag om spesifiek aanwendbare kennis van mensemateriaal te hê - daarom behoort daar in die opleiding van die studente in die bedryfsielkunde besondere klem op hierdie vaardigheid gelê te word. 'n Organisasie kan met reg aanspraak maak op die spesifieke vaardighede waarvoor hy die bedryfsielkundige in diens neem. Hierdie strenge eis van die praktyk plaas 'n verpligting op opleidingsinstansies om 'n stewige brug tussen teorie en praktyk te bou.

Bestuurders van ondernemings behoort egter ook touwys gemaak te word om vakkundiges beter in hul organisasies te kan benut. Dit sou trouens onwys wees om aan te dring op 'n algemene oriëntasie van die bedryfsielkundige - iets waaronder sy vakkundigheid dalk kan ly.

'n Verdere belangrike opleidingsvereiste is die sogenaamde metodiek van die bedryfsielkunde. Kursusse skiet tans in hierdie opsig moontlik tekort. Te min metodes en benaderingswyses word by die student tuisgebring (o.a. navorsingsmetodiek). Die persoon moet weet hoe om sy teoretiese kennis te kan toepas - hoe om dit te gebruik. 
b) Indien daar volkome aan die eise van die praktyk gehoor gegee moet word, wil dit voorkom asof die opleiding van die bedryfsielkundige in die toekoms meer "gerig" sal wees selfs vanaf die eerste jaar.

c) Daar bestaan na alle waarskynlikheid 'n leemte aan praktiese vaardigheid (ervaring?) by die bedryfsielkundige, veral gesien in die lig van die ervaring van bv. die medikus of die prokureur wat heelwat praktiese onderrig ondergaan alvorens hulle die beroepslewe betree.

Die gedagte is geopper dat van hierdie probleme dalk mag verval wanneer noukeurig gekyk word na die omskrywing van die begrip "bedryfsielkundige" volgens die Wet op Geneeshere, Tandartse en Aanvullende Gesondheidsberoepe, nr. 56 van 1974 (hierna genoem "die Wet"). Oor hierdie gedagte kon egter nie eenstemmigheid bereik word nie. ' $n$ Verdere mening is dat, selfs al het die bedryfsielkundige die akademiese agtergrond en een jaar internskap agter die rug, hy nog nie in die eerste, en selfs tweede jaar, vir 'n onderneming van groot nut kan wees nie. Hy kan dus nie oor dieselfde kam geskeer word as byvoorbeeld die mediese praktisyn nie.

\section{Behoefte aan sielkundige toetsing}

1. Bestaan daar volgens $u$ 'n vraag na opgeleide en geregistreerde toetsgebruikers?

2. Watter vlak (A, B of $C$ ) van toetsing is ter sprake in die praktyk?

3. Tot op watter vlak (A, B of $C$ ) meen u kan opleiding aan voorgraadse studente aangebied word?

4. Meen u opleiding in die gebruik van N.I.P.N.-toetse (soos tans in kursusse deur die N.I.P.N. aangebied) is nodig vir dosente van 'n Bedryfsielkunde-departement?

1. Dit blyk dat daar in die afgelope 3-4 jaar 'n fenomenale groei in die verkoop van toetse deur byvoorbeelddie N.I.P.N. en R.G.N., asook in die opleiding van toetsgebruikers was. Hiervolgens geoordeel is daar dus 'n besliste vraag na opgeleide toetsgebruikers.

2. Dit blyk verder dat die behoefte sal toeneem, veral wat betref kategorieë A en B toetse. Hierdie toetse word blykbaar in die praktyk meer aangewend vir klassifikasie by opleiding as vir keuringsdoeleindes.

Sommige instansies maak egter nie veel gebruik van alle vlakke van toetse nie. Dit hang grootliks af van die vlak van poste ter sprake en van die bestuursfilosofie wat in die besondere organisasie gehuldig word. 
Die praktyk is van mening dat hoër lone aan werknemers betaal word en dus moet daar meer wetenskaplik gekeur en opgelei word. Beter keuring sou ook meebring dat opleidingsprogramme meer wetenskaplik aangewend kan word om sodoende hoër dividende te lewer.

Ooreenkomstig navorsing aangehaal (2), blyk dit dat ondernemings positief gesind is teenoor die gebruik van toetse.

In baie gevalle waar dit nie gebruik word nie, is dit omdat fasiliteite en geskikte toetsafnemers ontbreek. Daar blyk ook 'n toenemende behoefte te wees aan C-vlak toetse en toetse vir die identifisering van bestuurstalent.

3. Nie behandel nie.

4. Die feit dat ' $n$ belangrike deel van die opleiding van die bedryfsielkundige die toepassing en interpretasie van toetse moet wees, is sterk onderstreep.

Wat betref vereistes vir registrasie as toetsgebruikers, kom die volgende feite aan die lig: Vir A-vlak toetse word persone, gewoonlik met matriekkwalifikasie, deur die N.I.P.N. gekeur - geen besondere sielkunde-opleiding word hier vereis nie. Vir B-vlak toetsing word bedryfsielkunde III of sielkunde III vereis en moet 'n kursus by die N.I.P.N. gevolg word. Vir C-vlak toetse moet die gebruiker by die S.A. Geneeskundige en Tandheelkundige Raad (Beroepsraad vir Sielkunde) - hierna genoem "die Raad" - geregistreer wees. Nuwe wetgewing kan moontlik 'n invloed op hierdie vereistes hê.

Sover dit die opleiding in die administrasie van N.I.P.N.-toetse betref, is laasgenoemde instansie bereid om, mits mannekrag dit toelaat en indien bevredigende reëlings getref kan word, opleidingskursusse vir universiteitsdepartemente en ander instansies aan te bied.

Met betrekking tot die gebruik van toetse, is daarop gewys dat die Wet vereis dat enige persoon wat sielkundige toetse hanteer, bevredigende onderrig moes ontvang het in psigodiagnostiek, psigopatologie en psigoterapie. A-vlak toetse val, volgens hierdie bepaling, nie onder die Wet nie.

Indien 'n persoon as psigotegnikus by die Raad geregistreer is (d.w.s. iemand in besit van 'n baccalareus-graad), kan hy wel toetse (op B-vlak) administreer, maar nie interpreteer nie. Interpretasiewerk moet deur 'n geregistreerde sielkundige gedoen word. 
Afgesien van hierdie vereistes van die Wet, blyk dit tog dat daar in die praktyk, vanweë die groot behoefte wat bestaan, toetsafnemers gebruik word wat nie die nodige kwalifikasies besit nie.

\section{BESKOUING VAN AKADEMICI}

\section{Patroon van opleiding van bedryfsielkundiges in Suid-Afrika}

1. By welke onderskeie instansies word bedryfsielkunde aangebied?

a) Is dit volgens $u$ oordeel 'n bevredigende toestand?

2. In welke universiteitsfakulteite vind bedryfsielkunde 'n tuiste?

a) Wat meen u is die rasionaal daaragter?

3. Watter hoofvak- en byvakkombinasies bestaan daar met bedryfsielkunde?

a) Meen u dat die bestaande kombinasies goed voorsien in die behoeftes wat daar in die Suid-Afrikaanse beroeps- en bedryfslewe bestaan?

4. In watter verskillende leergange by die verskillende opleidingsinstansies is die bedryfsielkunde 'n hoofvak?

a) Is die huidige bedeling, na u mening, bevredigend?

5. In welke grade/diplomas word minstens een kursus in die bedryfsielkunde aangebied?

a) Voel u dat die bedryfsielkunde langs hierdie weg voldoende "erkenning" geniet?

1. Tans word bedryfsielkunde by 15 universiteite aangebied, waarvan 6 formele afsonderlike departemente het. Daar word ook korter kursusse by kolleges en deur institute aangebied wat meer op praktiese aspekte van die vak gerig is.

Hoewel die registrasievereistes hoë eise stel aan die universiteite t.o.v. die bybring van basiese sielkundige agtergrond, die behandeling van al die hoofgebiede van die bedryfsielkunde, aanleer van spesifieke vaardighede en praktiese opleiding, sal die bestaande departemente wel hieraan kan voldoen.

Daar is egter ook ' $\mathrm{n}$ groot behoefte aan opleiding in die bedryfsielkunde deur persone wat nie uiteindelik wil registreer nie. Voorgraadse universiteitskursusse sowel as kursusse aangebied by ander instansies, vervul hier 'n belangrike funksie. Die kursusse aan kolleges en institute behoort dus nie verbied te word nie, hoewel hulle opleiding nie erken word vir 
registrasiedoeleindes nie, aangesien die bedryfsielkunde in hierdie kursusse nie so volledig, intensief en op dieselfde vlak as by universiteite bestudeer word nie.

2. Bedryfsielkunde word meesal as volwaardige studierigting in die handelsfakulteite van universiteite aangebied.

In sommige lettere en wysbegeerte-fakulteite kom die bedryfsielkunde wel tot sy reg, maar in andere nie. Enkele universiteite laat ook vakkombinasies in die natuurwetenskappe toe.

3. Een van die probleme met die opleiding van bedryfsielkundiges is dat alle beroepsgerigte vakkombinasies nie altyd moontlik is nie. Bedryfsielkunde word gewoonlik gekombineer met een of meer van ekonomie, bedryfsekonomie, bedryfsosiologie, arbeidswetgewing, kriminologie, kommunikasiekunde, bantoetale, volkekunde, maatskaplike werk, openbare administrasie, staatsleer en statistiek. Hierdie kombinasies dek in 'n groot mate die behoeftes van die verskillende bedrywe en beroepsfere waarin die bedryfsielkundige hom bevind.

Oor enige verpligte vakkombinasie met bedryfsielkunde, bestaan daar noodwendig uiteenlopende gedagtes. Sterk, fundamentele akademiese argumente is aangevoer waarom die bedryfsielkunde sy basiese koppeling binne die ekonomiese wetenskappe moet kry. Enige beswaar hierteen vind sy oorsprong in die van-dag-tot-dag-behoeftes van die praktyk en in die huidige universitêre bedeling in Suid-Afrika wat dit moeilik maak om nuttige aanvullende vakke (wat tradisioneel nie met die bedryfsielkunde assosieer is nie en dus ' $n$ teelaarde gevind het binne die konstellasie van nie-handelsfakulteite) met die bedryfsielkunde te koppel.

Om groter beweegruimte hier te bewerkstellig, het sekere universiteite in Suid-Afrika in die afgelope paar jaar nuwe graadkursusse in handelsfakulteite ingestel wat in geheel beskou, 'n groter verskeidenheid van kombinasies met die bedryfsielkunde moontlik maak, terwyl ander weer groter aansluiting by vakke in lettere en wysbegeerte-fakulteite soek.

4. Hoewel erken word dat ' $n$ groot aantal opgeleides in die sogenaamde handels- en "ekonomiese" bedrywe werk, behoort die B.Com leergang nie die enigste te wees waarbinne die bedryfsielkunde gevolg kan word nie. Ander beroepsgebiede soos navorsing, openbare dienste, kommunikasiewese, ontwikkelingsorganisasies en personeelbestuur van die Bantoe, noodsaak die insluiting van ander leergange wat vanweë die huidige universitêre opset in Suid-Afrika nie onder handelsfakulteite resorteer nie. Die huidige leergange van die grade 
B.Com, B.Econ., B.A., B.Admin. en B.P.L. behoort dus behou te word en almal moet uiteindelik kan lei tot registrasie ná voldoening aan alle ander vereistes.

Benewens die volwaardige bedryfsielkundekursusse word ook spesiale dienskursusse in ander leergange (bv. bosbou, ingenieurswese, huishoudkunde,ens.) aan sommige universiteite aangebied.

Besondere aard van die bedryfsielkunde

1. Watter kenmerke onderskei die bedryfsielkunde van die sielkunde?

2. Wat is die bedryfsielkunde se verhouding (akademies gesien) tot die ekonomiese en bestuurswetenskappe?

3. Wat is die bedryfsielkunde se verhouding tot die praktyk? M.a.w., het die praktyk 'n eiesoortige invloed op die inhoud, metodiek en tegnieke van die bedryfsielkunde?

4. Wat is die onderskeibare subvelde van die bedryfsielkunde?

a. Is daar verder, volgens $u$, 'n deurlopende rasionaal wat hierdie subvelde aan mekaar koppel? M.a.w., sluit die een subveld logies aan by die volgende? Indien wel, wat is dié Logika?

5. Wat onderskei die bedryfsielkunde van ander vakke soos bedryfsosiologie, bedryfsekonomie, nagraadse bestuursopleiding?

a. Wat is die aard van hierdie onderskeidende kenmerke? Is dit inhoud, oriëntasie, metodiek, vlak van aanbieding, wat nog?

1. Nie behandel nie.

2. Die vak het veral baie noue bande met die ekonomiese en bestuurswetenskappe omdat mannekrag in ooreenstemming met beginsels onderliggend aan hierdie wetenskappe ten beste benut moet word en die bedryfsielkundige die kennis en vaardigheid hiertoe het.

3. Nie behandel nie.

4. Die spesifieke onderwerpe van die vak kan ingedeel word in die volgende ses subvelde: personeelsielkunde, organisasiesielkunde, verbruikersielkunde, ergonomika, beroepsielkunde en psigometrika/navorsingsmetodiek.

Die gebiede van die psigodiagnostiek, psigopatologie en psigoterapie word vereis vir registrasie en word tans reeds op voorgraadse en nagraadse vlak deur verskeie universiteite 
aangebied. Dit vorm veral op voorgraadse vlak soms afdelings van groter kursuseenhede soos beroepsielkunde, personeelsielkunde, ensovoorts.

Benewens bogenoemde bied sommige universiteite ook kursusse in psigososiale verskille, bedryfsberaad, kollektiewe bedinging, openbare verhoudinge en industriële verhoudinge aan.

5. Nie behandel nie.

\section{Opleidingsprogramme}

1. Wat is die inhoud van elk van die subvelde in die voorafgaande vraag 4?

2. Behoort enige wesentlike onderskeid getref te word tussen voor-en nagraadse opleiding? Indien wel, omlyn die wesensverskil, bv. inhoudelik, kwalitatief (vlak van aanbieding) en kwantitatief?

3. Is daar enige wesentlike onderskeid te tref tussen opleiding in die lste, 2de en 3de jaar? Indien wel, hoedanig?

4. Hoe word die kriteria van breë opleiding, spesialisasie, beroepsgerigtheid en akademiese skoling in voor- en nagraadse opleiding bevredig?

5. Is daar enige ander kriteria (nie in 4 genoem) van belang by opleiding in die bedryfsielkunde?

6. Word lste, 2de en 3de jaar kursusse as afgeronde opleidingseenhede beskou? Indien wel, wat is die rasionaal daaragter? Indien nie, waarom nie?

7. Hoedanig word klem gelê op praktiese werk? Wat is die rasionaal daaragter?

8. Wat is die aard van die praktiese werk, bv. laboratoriumwerk, veldwerk, vakansiewerk?

9. Hoe word oorvleueling tussen subvelde van die bedryfsielkunde hanteer?

10. Hoe word "oorvleueling" met die sielkunde hanteer?

11. Hoe word oorvleueling met ander vakke hanteer, bv. Bedryfsekonomie, bedryfsosiologie?

12. Wat is die voor-en nadele verbonde aan die aanbieding van dienskursusse (spesiale bedryfsielkunde-kursusse) aan studente uit ander fakulteite?

13. Watter geleentheid is daar vir dosente om binne die subvelde van die bedryfsie lkunde te spesialiseer? Is dit wenslik of nie? 
14. Hoe word die suiwer sielkunde as grondslag van die bedryfsielkunde hanteer in die aanbieding van kursusse. D.w.s., in hoe 'n mate word daar op die suiwer sielkunde gesteun?

15. Watter vereistes word daar vir 'n magistergraad gestel? Indien slegs 'n verhandeling, is dit voldoende? Indien nie, wat moet bykom?

16. Hoeveel geleentheid vir werk by geakkrediteerde organisasies is daar met die oog op registrasie by die Geneeskundige en Tandheelkundige Raad (Beroepsraad vir Sielkunde)?

1. Nie behandel nie.

2 en 3. Meestal word 'n onderskeid getref tussen voor- en nagraadse kursusse. Voorgraads word probeer om die hele terrein van die vak te dek op 'n beskrywende en vaardigheidsvlak. Nagraads word dieselfde inhoud weer gedek, maar wyer in omvang, in heelwat meer diepte en meer navorsingsgeoriënteerd.

Dit is egter nog nie duidelik of die registrasievereistes breër opleiding gaan vereis op voorgraadse of op nagraadse vlak nie.

4. Die relatiewe hoeveelheid tyd en aandag wat aan elk van die onderafdelings bestee behoort te word, is nie uitgepluis nie, en behoort 'n nuttige onderwerp vir latere bespreking te wees.

5. Nie behandel nie.

6. By die meeste universiteite word in die eerste studiejaar, sielkundige agtergrond aangebied. Verder word 'n inleiding tot die bedryfsielkunde aangebied, wat wissel van enkele voorlesings tot 'n hele semesterkursus. Hoewel sommige universiteite dit as prakties onmoontlik beskou, probeer ander tog om elke jaargang tot 'n funksionele eenheid af te rond, omdat baie studente die vak net tot aan die einde van die eerste of tweede jaar volg.

7. Praktiese werk bly steeds ' $n$ netelige kwessie. Sommige universiteite behaal sukses met verpligte vakansiewerk in organisasies, sodat 'n mate van beroepservaring en insig in die funksionering van mense in organisasies verkry kan word. Dit word veral voor die derde jaar gedoen en duur tot twee maande.

Vir nagraadse nie-residensiële studente, word daar by een universiteit beoog om een week voltydse verpligte opleiding in 'n laboratorium in te stel. 
Een universiteit bied nagraadse kursusse net na-uurs aan sodat studente verplig word om praktiese ondervinding saam met hul studie te verkry.

Voorgraadse opleiding word deur sommige universiteite aangevul deur rolspelaktiwiteite, gevallestudies, kleingroepbesprekings en demonstrasies.

8. Die meeste universiteite vereis praktiese navorsingsprojekte van beperkte omvang in die nagraadse studie, waarby eerstejaarstudente soms betrek word as proefpersone.

Die aanbieding van kwantitatiewe metodes en psigometrie kan bevorder word deur byvoorbeeld alle eerstejaars 'n goedgekose toetsbattery te laat doen en die gegewens deurlopend tot op nagraadse vlak te gebruik vir verskillende toepassings deur die groep toetslinge self.

9-16. Nie behandel nie.

\section{Navorsing}

1. Wat is die aard van navorsing wat meestal deur bedryfsielkundiges gedoen word? (Bv. basies, toegepas, probleemoplossing, metodologies).

2. Watter soort van navorsingsversoeke word meestal aan bedryfsielkundiges deur die praktyk gerig?

1-2. Nie behandel nie.

\section{VEREISTES VAN PROFESSIONELE LIGGAME}

\section{Etiese skoling}

1. Word die etiese kode vir sielkundiges, soos deur Sirsa aanvaar, as voldoende beskou vir bedryfsielkundige werk?

2. Is daar enige addisionele gedragskodes wat oorweging verdien?

1. Soos blyk uit die onderstaande bespreking, hou die bestaande etiese kode ernstige implikasies vir die werk van die bedryfsielkundige in die praktyk in.

Die grondoorsaak van die probleern lê waarskynIik daarin dat die etiese kode, soos deur die Sielkundige Instituut van R.S.A. en die S.A. Sielkundige Vereniging aanvaar, oorspronk- 
lik vir en deur klinici geformuleer is en dat die kode (wat vanuit bedryfsielkundige hoek gesien, soms onuitvoerbaar is) later 'n baie sterk neerslag in die Wet gekry het.

2. Geen addisionele gedragskodes blyk as sodanig geskik te wees nie, hoewel, gesien die ontevredenheid met die bestaande, enige wysiging na verwagting verwelkom sou word.

\section{Registrasie by professionele liggame}

1. Behoort alle bedryfsielkundiges te registreer as toetsgebruikers? Indien wel, stel huidige opleidingsprogramme hul in staat om dit wel te kan doen?

2. Is die huidige registrasievereistes vir bedryfsielkundiges, soos deur die Geneeskundige en Tandheelkundige Raad (Beroepsraad vir Sielkunde) voorgeskryf, aanvaarbaar? Indien nie, hoedanig behoort dit gewysig te word?

3. Watter vereistes word gestel vir akkreditering van universiteitsdepartemente?

1. Nie behandel nie.

2. Die doelstellings van die Wet is om die term "sielkundige" te beskerm. Enige persoon wat dus sielkundige werk verrig, moet geregistreer wees by die Raad.

Die bedryfsielkundige word dus hierby ingesluit en sal aan die vereistes van die Wet moet voldoen voordat hy as professionele bedryfsielkundige kan praktiseer.

Voordat enige persoon kan registreer as 'n bedryfsielkundige, moet hy in besit wees van 'n erkende magistergraad sowel as 'n bewys van ten minste 12 maande internskap wat by 'n geakkrediteerde instansie voltooi is. Die geakkrediteerde instansies moet voldoen aan die vereistes soos neergelê deur die Raad.

As oorgangsmaatreël is daar sekere uitsonderinge wat gemaak word ten opsigte van persone wat voor 1 Januarie1940 gebore is en vir ten minste 5 jaar deurlopend sy brood op die gebied van die sielkunde (of bedryfsielkunde) verdien het.

'nVerdere uitsondering word moontlik gemaak deur artikel 20 van die Wet. Volgens die vertolking wat blykbaar hieraan geheg word, kan vrystelling van 2 tot 3 jaar verleen word aan persone in die praktyk ten einde geleentheid te kry om te voldoen aan die vereistes van die Raad. Dit beteken dus nie dat sodanige persoon kwytskelding verkry nie, maar slegs 'n geleentheid om aan die vereistes te voldoen. 
Die Wet hou vir bedryfsielkundiges besondere implikasies in. Die algemene uitgangspunt is dat enige sielkundige/bedryfsielkundige aan die volgende breë vereistes moet voldoen: (a) bedrewe wees op die gebied van die psigodiagnostiek (b) bedrewe wees in die herkenning van psigopatologie (c) bevoeg wees in die toepassing van psigoterapie. (Binne die raamwerk van die bedryfsielkunde sou die aanbieding van bv. T-groepopleiding of bestuursontwikkeling beskou word as die toepassing van terapie. )

Wat toetsing betref, bepaal artikel 23 dat 'n persoon wat in besit is van ' $n$ toepaslike B.graad en 6 maande internskap, kan registreer as 'n psigotegnikus. Sodanige persone mag slegs toetse administreer, maar mag dit nie interpreteer nie.

A-vlak toetse word nie beskou as sielkundige toetse nie en word nie omskryf in die Wet nie. Enige persoon kan dus sodanige toetse toepas sonder dat hy geregistreer is as bedryfsielkundige. Sodra toetse egter geklassifiseer is as sogenaamde B-vlak en C-vlak toetse, moet voldoen word aan die vereistes van die Wet voordat sodanige toetse toegepas kan word.

Die algemene uitgangspunt ten opsigte van advertensies is dat geen professionele persoon sy dienste mag adverteer nie. Die kwaliteit van diens wat 'n persoon lewer, moet die enigste advertensie van sy produk wees. Dit beteken dat rondskrywes waarin 'n konsultant sy dienste onder die aandag van potensiële klante bring (en wat vandag as normale praktyk deurgaan) volgens wet nie mag geskied nie. 'n Bekendstellingskaartjie sou, volgens die vertolking van die Wet tydens die samesprekings, wel in orde wees en 'n verbale "individuele" advertensie waar 'n konsultant die toekomstige lewering van sy dienste bekend stel, sou ook binne die kader van die Wet val.

Dit blyk duidelik uit bostaande byna-inkonsekwenthede dat daar in die toepassing van die bestaande Wet 'n groot mate van buigsaamheid sal moet wees. Die kliniese model, wat baie duidelik in die Wet weerspieël word, lê ongetwyfeld die aktiwiteite van die bedryfsielkundige aan bande. Een van die belangrikste redes hiervoor is dat die inrigting- en spreekkameropset nie in die bedryfslewe bestaan nie. In die vertolking en toepassing van die Wet, sal hierdie nie-konvensionele werksomgewing van die sielkundige in ag geneem moet word.

Artikel 31 van die Wet het spesifiek betrekking op universiteite. Dit kom daarop neer dat indien 'n bepaalde universiteit in gebreke bly om te reageer wanneer hy gevra word om 'n voorlegging van sy leerplanne, mag dit gebeur dat sodanige universiteit se grade nie in 
aanmerking kom vir registrasiedoeleindes nie. Tot aan die einde van 1977 word alle magistergrade aan Suid-Afrikaanse universiteite aanvaar vir registrasiedoeleindes. Die gedagte is om ná 1977 waarskynlik ernstige oorweging te verleen aan meer gerigte opleiding.

3. Kommer bestaan oor die beperkte aantal opleidingsinstansies wat tans geakkrediteer is en oor die vraag of ' $n$ intern wel binne die bestek van 12 maande voldoende opleiding sou kon ontvang in alle fasette van die bedryfsielkunde soos vasgelê deur die Raad.

Hoewel daar tans min organisasies vanweë ekonomiese en praktiese redes geakkrediteer is, word dit tog voorsien dat organisasies in die toekoms alhoemeer die belegging sal moet maak en heeltydse geregistreerde bedryfsielkundiges sal moet aanstel. Sodoende sal hul nie alleen kan meehelp in die opleiding van interns nie, maar sal ook sorg dat hul eie aktiwiteite aan al die vereistes van die Wet voldoen.

Die voorgestelde kriteria vir opleiding van intern-bedryfsielkundiges, word ook as onrealisties beskou, aangesien dit nie voorsiening maak vir praktiese ervaring op al die terreine van die bedryfsielkunde nie. Personeelsielkunde en organisasieleer as subvelde van die bedryfsielkunde word daarin oorbeklemtoon, terwyl die ergonomika, die beroepsielkunde en die verbruikersielkunde geen aandag kry nie.

Hoewel dit oor die algemeen aansienlike kostes sou meebring, is dit tog in die vooruitsig gestel en as baie wenslik beskou dat Bedryfsielkunde-departemente aan universiteite uiteindelik sal registreer as opleidingsinstansies vir intern bedryfsielkundiges.

Institute wat gekoppel word aan Bedryfsielkunde-departemente, sou uiteraard in 'n posisie kan wees om as opleidingsinstansie te registreer.

Ten spyte daarvan dat aansienlike probleme in die toepassing van die Wet voorsien word, behoort dit gestel te word dat bedryfsielkundiges gevra het vir wetgewing om hul te beskerm en derhalwe moet hierdie betrokke wetgewing as 'n stap in die regte rigting beskou word. Daar kan ook nie verander word aan hierdie wet nie, behalwe deur wetgewing in die parlement. Praktiserende bedryfsielkundiges sal dus sorg moet dra dat hulle voldoen aan die vereistes van die Wet sodat hulle geregistreer kan word.

Die praktiese probleme by die implementering van die Wet en die andersheid van die omgewing waarin die bedryfsielkundige funksioneer, noodsaak egter 'n groot mate van buigsaamheid aan die kant van die Raad. In retrospek lyk dit tog asof die Wet opgestel is met min inagneming van die eieaardigheid van bedryfsielkundige praktyk. Waarskynlik is dit so Perspektiewe in die Bedryfsielkunde 19762.3 
dat die bedryfsielkundige sy stem in hierdie saak nie duidelik genoeg laat hoor het nie moontlik omdat die nodige platform daarvoor (soos bv. 'n simposium vir alle betrokkenes) nie vroegtydig geskep is nie.

\section{VERWYSINGS}

1. De Villiers, W.S. Praktiese Aspekte van Bedryfsielkunde met Verwysing na die Implikasies wat dit Inhou vir die arbeidsituasie in S.A. Referaat, Sirsa-kongres, 1974. (pp.10-26).

2. Langenhoven, H.P. en Verster, P. Sielkundige Toetsing in die Bedryf. U.O.V.S., Afd. Personeelnavorsing, nr. P/17, 1973.

3. Marx, F.W. Opleiding in Personeelbestuur in S.A. Pretoria: Publikasie van die Universiteit van Pretoria, Nuwe reeks nr. 54. 1969.

4. Orpen, C. The image of industrial psychology among South African business executives: an empirical study. Jourmnal of Behavioral Science, 1972, 1(4), 245-246.

5. Raubenheimer, I. van W. Die Houding in Enkele Suid-Afrikaanse Nywerhede teenoor die Bedryfsielkundige en sy Funksies. Potchchefstroom: M.Comn.-verhandeling. P.U. vir C.H.O., 1964.

6. Raubenheimer, I. van W. Enkele Gedagtes oor die Opleiding van Bedryfsielkundiges in Suid-Afrika. Referaat, Sirsa-kongres, 1974. (pp. 512).

7. Raubenheimer, I. van W. Industrial psychology in South Africa. Psychologia Africana, 1974, 15(2), 111-118.

8. Vlok, A. Die beroepsbeeld van die bedryfsie1kundige. Suid-Afrikaanse Sielkundige, 1974, 4(1), 23-28. 